\title{
How warmer and drier will the Mediterranean region be at the end of the 21st century?
}

Philippe Drobinski, Nicolas Da Silva, Sophie Bastin, Sylvain Mailler, Caroline Muller, Bodo Ahrens, Ole B. Christensen Piero Lionello

P. Drobinski, N. Da Silva, S. Mailler, C. Muller: LMD/IPSL, Ecole Polytechnique, Institut Polytechnique de Paris, ENS, PSL Research University, Sorbonne Université, CNRS, Palaiseau, France S. Bastin : LATMOS/IPSL, UVSQ, Université Paris-Saclay, Sorbonne Université, CNRS, Guyancourt, France

B. Ahrens: Institute for Atmospheric and Environmental Sciences, Goethe-University Frankfurt, Frankfurt, Germany

O.B. Christensen : Danish Meteorological Institute, Copenhagen, Denmark

P. Lionello : CMCC, Lecce, Italy

\begin{abstract}
Nearly all regions in the world are projected to become dryer in a warming climate. Here, we investigate the Mediterranean region, often referred to as a climate change "hot spot". From regional climate simulations, it is shown that although enhanced warming and drying over land is projected, the spatial pattern displays high variability. Indeed, drying is largely caused by enhanced warming over land. However, in Northern Europe, soil moisture alleviates warming induced drying by up to $50 \%$ due to humidity uptake from land. In already arid regions, the Mediterranean Sea is generally the only humidity source and drying is only due to land warming. However, over Sahara and the Iberian Peninsula, enhanced warming over land is insufficient to explain the extreme drying. These regions are also isolated from humidity advection by heat lows, which are cyclonic circulation anomalies associated with surface heating over land. The cyclonic circulation scales with the temperature gradient between land and ocean which increases with climate change, reinforcing the cyclonic circulation over Sahara and the Iberian Peninsula, both diverting the zonal advection of humidity to the south of the Iberian Peninsula. The dynamics are therefore key in the warming and drying of the Mediterranean region, with extreme aridification over the Sahara and Iberian Peninsula. In these regions, the risk for human health due to the thermal load which accounts for air temperature and humidity is therefore projected to increase significantly with climate change at a level of extreme danger.
\end{abstract}

Keywords

Water cycle ; Warming ; Dryness ; Clausius-Clapeyron law ; Heat lows ; Regional climate change ; Human health ; Europe ; Mediterranean ; HyMeX ; MED-CORDEX

\section{Introduction}

The Mediterranean region, i.e. the region of lands around the Mediterranean Sea that have a Mediterranean climate (Köpen, 1936), has been identified as one of the most sensitive and vulnerable region in the world to climate change (e.g. Giorgi, 2006), with a projected increase in interannual rainfall variability in addition to a strong warming and drying for 2080-99 compared with 1980-99.

Analyses of observation-based data show that the Mediterranean region has tended to be warmer and drier during the last half century. Mariotti et al. (2015) estimate over the 1960-2005 period the annual mean precipitation trend to be about $-22 \mathrm{~mm}$ per decade for the last century and the annual mean surface air temperature trend to be $0.19-0.25^{\circ} \mathrm{C}$ per decade. When considering only the summer surface air temperature, the warming trend over the Mediterranean region for the last decades of the 20th century ranges between $0.08^{\circ} \mathrm{C}$ to $0.3^{\circ} \mathrm{C}$ per decade (Xoplaki et al., 2003; Solomon et al., 2007; Mariotti et al., 2015). An increasing frequency of record breaking heat waves has been observed in the recent decades (Christidis et al., 2014 ; Russo et al., 2015). 
With the ongoing anthropogenic climate change, a further increase in the number of heat waves in the upcoming decades is very likely (IPCC, 2013). Within the climate change scenarios, the already observed warming and drying are further amplified in the Mediterranean (e.g. Giorgi, 2006; Mariotti et al., 2008). The temperature in the Mediterranean is expected to warm $20 \%$ more than the global average (Lionello and Scarascia, 2018). A strong warming is projected, ranging between +1.4 and $5.8^{\circ} \mathrm{C}$ for 2080-99 when compared with 1980-99 from the models and scenarios of the $3^{\text {rd }}$ Coupled Model Intercomparison Project (CMIP3; Giorgi, 2006). Such warming is still consistent in the future Mediterranean climate projections of the $5^{\text {th }}$ Coupled Model Intercomparison Project (CMIP5; Drobinski et al. 2018a) with an associated increase of the number, duration and spatial extension of dry spells (Raymond et al., 2019). Several studies already refer to «mega-heatwave » (Stegehuis et al., 2015 ; Bador et al., 2017).

More frequent, longer and more intense heatwaves and droughts in the future raises serious concerns about the impact of such extreme events on the economic activities, biodiversity and on public health (e.g. Fouillet et al. 2006). Indeed, the Mediterranean region is not only a climate hot spot, it is also one biodiversity hot spots that has lost at least 70 percent of its original habitat (Meyers et al., 2000; Cuttelod et al., 2008). High temperature associated with a strong variability of humidity is a health risk factor for population, which exposure may increase dramatically not only because events conducive to heatwaves and droughts, but also because of the population growth.

There is therefore a need to refine the existing temperature and humidity projections at a spatial scale relevant for impact studies on human health. Identifying regional key spots of heatwaves and droughts in order to map vulnerable areas has been carried out with simple metrics, like the duration and/or extent of warm and dry spells, that are useful for analyzing temporary anomalies (e.g. Stéfanon et al., 2012a; Raymond et al., 2016, 2018a,b). However, the processes controlling background drying, rather than temporary anomalies, and their interlinkages are missing and prohibiting their translation into impact on human health. This study therefore addresses the following questions:

- do temperature and humidity changes vary spatially?

- do land surface processes control humidity uptake from land into the atmosphere?

- do dynamical processes affect temperature and humidity changes?

- do temperature and humidity changes affect risk for human health ?

This study investigates these questions using simulations performed within the context of the HyMeX (Drobinski et al., 2014) and EURO- and MED-CORDEX (Jacob et al., 2014; Ruti et al., 2016) programs for present day and future climate.

Section 2 briefly lists the models used and the numerical set-up. Section 3 analyses how and at which spatial scales humidity and temperature change with regional climate warming. It investigates the role of land uptake in humidity change and discusses a possible dynamical cause of temperature and humidity changes, in relation with occurrence of regional heat lows. Section 4 quantifies the impact of humidity and temperature change on human health and relates the impact to the regional atmospheric circulation. Section 5 concludes this study and discusses some open research questions needing further investigation.

\section{Simulation set-up and models}

Regional climate simulations from five regional climate models of the joint HyMeX/MED-CORDEX programs (Drobinski et al. 2014; Ruti et al. 2016) and the EURO-CORDEX program (Jacob et al. 2014) are analyzed. The five regional climate models (CCLM4-8-19 operated by CMCC, CCLM4-8-18 by GUF, HIRHAM5 by DMI, RACMO22E by KNMI and WRF331F by IPSL and INERIS) have a horizontal resolution of about $50 \times 50 \sim \mathrm{km}^{2}$ and are driven by six different global climate models (GCMs) for high end scenario RCP8.5, where RCP stands for Representative Concentration Pathways (IPCC, 2013). All models use the 6-h meteorological variables from the CMIP5 historical and projection runs as forcing data at the boundaries (CMCC-CCLM4-8-19 driven by CMCC-CM, GUF-CCLM4-8-18 by MPI-ESM-LR, DMI-HIRHAM5 and KNMI-RACMO22E by ICHEC-EC-EARTH and IPSL-INERIS- 
WRF331F by IPSL-CM5A-MR). The mean global warming projections for RCP8.5 by the CMIP5 models is $2.0^{\circ} \mathrm{C}$ for $2046-2065$, with a likely range of 1.4 to $2.6^{\circ} \mathrm{C}$. It increases up to $3.7^{\circ} \mathrm{C}$ with a likely range of 2.6 to $4.8^{\circ} \mathrm{C}$ at the $2081-2100$ horizon.

\section{Temperature and humidity change analysis}

Lionello and Scarascia (2018) show that the Mediterranean region warms 20\% more than the global average. Figure 1 displays the spatial pattern of the temperature change between 2070-2100 and 19792005 for the four seasons. Over the sea, there is a zonal gradient with a temperature change ranging between $+1.5^{\circ} \mathrm{C}$ in winter (Fig. 1a) to $+2.5^{\circ} \mathrm{C}$ in summer (Fig. 1c) along the Atlantic facade and up to $+3.5^{\circ} \mathrm{C}$ over the Eastern sub-basin of the Mediterranean Sea. Land surrounding the Mediterranean Sea can be twice warmer than the neighbouring Atlantic Ocean and Mediterranean Sea. Over the land, there is a North-South divide regarding temperature change in spring (Fig. 1c) and summer (Fig. 1d). In the Southern Mediterranean, the temperature change is fairly homogeneous from Morroco to Egypt and ranges between $+2^{\circ} \mathrm{C}$ in winter and about $+6^{\circ} \mathrm{C}$ in summer. Penetration of slightly colder air from the Mediterranean Sea over Libya by coastal circulation is visible and can reach -0.5 to $-1^{\circ}$ with respect to the neighboring countries. Over Europe, there is a significant zonal gradient in winter which goes from $+1.5^{\circ} \mathrm{C}$ over Western Europe to $+6^{\circ} \mathrm{C}$ over Russia. The zonal gradient is lower in spring and autumn ranging between $+2^{\circ} \mathrm{C}$ to the West and $+4^{\circ} \mathrm{C}$ to the East. In summer, a meridional gradient dominates over the zonal gradient. The temperature change reaches $+5^{\circ} \mathrm{C}$ over the Northern Mediterranean to $+3^{\circ} \mathrm{C}$ in Northern Europe. The zonal gradient of temperature change in Northern Europe, occurring in winter and autumn particularly, is largely due to the dominating westerlies which advects cold and moist air from the Atlantic Ocean, as is shown in Fig. 1 (panels a and d) with the ensemble mean wind field overlaid on top of the temperature change pattern. Enhanced warming of land surfaces relative to oceans thus occurs simply because continental air masses are drier than maritime ones, which in turn is a consequence of the limited availability of surface water.

Temperature and humidity changes are linked. Humidity evolves with respect to Clausius-Clapeyron (CC) law which has been used as a predictor of the changes in humidity with global warming. The increase in the saturation water vapor pressure associated with warming is described by the CC relation:

$$
\frac{\partial e_{S}}{\partial T}=\frac{L_{v} e_{S}}{R_{v} T^{2}}
$$

where $e_{s}$ is the saturation water vapor pressure, $T$ is the absolute atmospheric temperature in Kelvin, $L_{v}$ is the latent heat of vaporization and $\mathrm{R}_{\mathrm{v}}$ is the gas constant. The $\mathrm{CC}$ scaling has also been linked to changes in precipitation extremes under observed (Drobinski et al., 2016, 2018a) and future warmer climates (e.g. Trenberth et al. 2003; O'Gorman and Muller 2010; Muller et al. 2011; Drobinski et al., 2018a). Figure 2 displays the ensemble mean of the simulated humidity change relative to the prediction following the CC-scaling for the four seasons. The humidity change prediction assuming a CC-scaling is obtained by shifting the current climate humidity by applying the CC scaling to the simulated temperature change. In other words, let us denote $\mathrm{e}(\mathrm{T})$ the water vapor pressure at temperature $\mathrm{T}$ and $\mathrm{e}_{\mathrm{s}}(\mathrm{T})$ the corresponding water vapor pressure at saturation. Figure 2 displays the ratio

$$
\frac{\Delta e}{\Delta e_{S}}=\frac{\left(e\left(T_{F}\right)-e\left(T_{P}\right)\right)}{\frac{\partial e_{S}}{\partial T}\left(T_{P}\right)\left(T_{F}-T_{P}\right)}
$$

where $T_{P}$ and $T_{F}$ are the temperatures at present and future climates, respectively and the $\Delta$ operator indicates the change between the present and future climates. In the following sections, this ratio will be referred as the relative change of humidity. When its value is close to 1 , the humidity change thus follows the CC law (i.e. the relative humidity remains constant in a warmer climate). Figure 2 shows that whatever the season, the humidity change follows a CC-scaling over the seas (Atlantic Ocean, Channel, North and Baltic Seas, Mediterranean and Black Seas), in agreement with observations (Dai, 2006). Humidity change is closer to CC-scaling along the coasts than further inland because of moisture advection from the seas and the still limited warming over land due to the damping effect of the nearby presence of the seas. Indeed, efficient moisture transport can be ensured by coastal wind systems such as breeze (Bastin et al. 2007; Drobinski et al., 2018b). Further inland, significant sub-CC scaling is a dominating feature especially from spring to fall with, however large spatial variability (Fig. 2). In winter, there is a strong divide between Northern and Southern Mediterranean regions. The Northern 
side of the Mediterranean shows a relative humidity change close to 1 , so the humidity change follows the CC-law. The aridity of the inland regions of North Africa prevents any additional moisture source so that the relative humidity change is much smaller than the $\mathrm{CC}$ prediction. The Atlas region and the Middle East display very low values of humidity change. It never exceeds $30 \%$ and can be lower than $10 \%$ in spring. In the Northern shore of the Mediterranean Sea, the Iberian Peninsula seems peculiar. Indeed, except for winter, it always display very low humidity change, suggesting limited moisture source to compensate for temperature rise.

\subsection{Humidity uptake from land}

Sherwood and Fu (2014) suggested that the key factor causing drying is that land surfaces warm more than ocean surfaces. A factor ensuring drying is that water vapor content over land does not increase fast enough relative to the rapid warming there. When this air moves onto land, its water vapor content reflects the amount that it held originally (Rowell and Jones, 2006). Figure 3 displays the zonal variation of the humidity change $\Delta \mathrm{e} / \Delta \mathrm{e}_{\mathrm{s}}$ along the cross-sections (see Fig. 1) and the change expected if the origin of the water vapor content was from the upstream ocean only $\Delta \mathrm{e}^{\text {up }}$ sea $/ \Delta \mathrm{e}_{\mathrm{s}}$. In other words, it corresponds to the ratio $\Delta \mathrm{T}^{\mathrm{up}}$ sea $/ \Delta \mathrm{T}_{\text {land }}$ because

$$
\frac{\Delta e_{\text {sea }}^{u p}}{\Delta e_{S}} \approx \frac{\Delta e_{S, s e a}^{u p}}{\Delta e_{S}} \approx \frac{\frac{\partial e_{S}}{\partial T\left(T_{P}\right)} \times \Delta T_{\text {sea }}^{u p}}{\frac{\partial e_{S}}{\partial T\left(T_{P}\right)} \times \Delta T}=\frac{\Delta T_{\text {sea }}^{u p}}{\Delta T}
$$

The quantity $\Delta \mathrm{T}^{\mathrm{up}}$ sea is the temperature change over the sea upstream of a given land location along the cross sections (NEUR, NMED and SMED in Fig. 2a). It uses the wind pattern to identify the upstream location over the sea at which the temperature change is computed. Indeed, the wind pattern displayed with black and white arrows for present and future climates, respectively, evolves very weakly with climate change. The quantity $\Delta \mathrm{T}^{\mathrm{up}}$ sea is directly linked to the humidity change over the sea. In Fig. 3, the yellow stripes display the regions over the sea. Above this regions, the humidity change $\Delta \mathrm{e} / \Delta \mathrm{e}_{\mathrm{s}}$ is close to one as it follows CC-scaling.

As expected, over Northern Europe (NEUR), drying is significant. Because the land warms faster than the oceans, the humidity of the arriving air does not increase enough to maintain a constant relative humidity. However the noticeable feature is that dryness would be larger if the air masses moving eastwards from the Atlantic Ocean would only carry marine water. Indeed, Fig. 3 shows that, for all seasons but summer, $\Delta \mathrm{e} / \Delta \mathrm{e}_{\mathrm{s}}$ is always significantly larger than the humidity change $\Delta \mathrm{e}^{\mathrm{up}}{ }_{\text {sea }} / \Delta \mathrm{e}_{\mathrm{s}}$ which assumes the upstream ocean as the only humidity source. Therefore, in Northern Europe, a significant humidity uptake from the land compensates in part the dryness produced by enhanced warming over land. This effect is maximum during winter, weaker but still significant during spring and autumn and non significant in summer suggesting soil moisture limited conditions (the two curves are not significantly different), as already suggested in Bastin et al. (2019). Quantitatively, warming alleviates drying by $15 \%$ (autumn and spring) to $50 \%$ (winter) due to humidity uptake from land.

Along SMED (Southern shore of the Mediterranean Sea), Fig. 3 does not reveal any significant difference between $\Delta \mathrm{e} / \Delta \mathrm{e}_{\mathrm{s}}$ and $\Delta \mathrm{e}^{\mathrm{up}}{ }_{\text {seal }} / \Delta \mathrm{e}_{\mathrm{s}}$. It is not a surprise as these regions are extremely arid so the only moisture source actually comes from the surrounding seas. An exception is the Sahara in autumn and winter, where the humidity change $\Delta \mathrm{e} / \Delta \mathrm{e}_{\mathrm{s}}$ is this time weaker than the humidity change $\Delta \mathrm{e}^{\mathrm{up}}{ }_{\text {sea }} / \Delta \mathrm{e}_{\mathrm{s}}$. The specific case of the Sahara region is very similar to that of the Iberian Peninsula. Indeed, along the Northern shore of the Mediterranean Sea (NMED), the Iberian Peninsula displays a humidity change $\Delta \mathrm{e} / \Delta \mathrm{e}_{\mathrm{s}}$ weaker than $\Delta \mathrm{e}^{\mathrm{up}}{ }_{\text {sea }} / \Delta \mathrm{e}_{\mathrm{s}}$, consistent with the very little change in humidity there (blue region in Fig. 2). Over these regions which are extremely arid, the land thus becomes a humidity sink for the atmosphere.

Figure 4 shows the relative change of ratio of precipitation to potential evapotranspiration (P/PET), computed from Priestley-Taylor method (Priestley and Taylor, 1972), and the relative change of the ratio of precipitation to real evapotranspiration (P/ET). On average, on all continents, P/PET fall, consistent with model simulations (O'Gorman and Muller, 2010) and observations (Simmons et al., 
2010). The gap between actual and saturation water vapor concentration which is the key factor controlling PET, grows much faster in percentage than do other hydrological quantities, inducing enhanced aridity. Along NEUR, the change of P/PET and the change of P/ET are not significantly different, suggesting that the soil is humid enough in that region so the real evapotranspiration and the potential evapotranspiration do not differ much. The change of P/PET and the change of P/ET are slightly negative as one would expect (e.g. Sherwood and Fu, 2014), but still not far from 0. Indeed, despite a precipitation increase in this region, evapotranspiration increases slightly faster because of enhanced warming over land, but also because of enough moisture availability.

Along SMED, Fig. 4c shows this time a significant difference between P/PET and P/ET changes. In this region, not only precipitation and evapotranspiration take very low values on average, but also changes of precipitation and evapotranspiration are close to zero. This leads to a noisy estimation of the relative change of P/PET and the change of P/ET (to make the figure legible, the uncertainty range is shown for an interval of $\sigma / 10$ for the South Mediterranean cross-section). However, there is a clear dryness increase since P/PET decreases significantly (between -200\% and -300\% in Fig. 4c). Increase in PET is therefore attributable to overall land warming rather than relative humidity change as also suggested by Scheff and Frierson (2013), and the P/PET ratio on land is reduced largely by the enhanced land warming relative to oceans in the Southern Mediterranean region. The relative change of P/ET varies around zero because all terms are close to zero and do not vary in time significantly.

One can therefore ask how the land uptake of atmospheric humidity over the Iberian Peninsula and the Sahara seen in Fig. 3 can be explained. The most likely explanation in this context is to consider processes not directly related to local energy and water "recycling". These regions have specific physiographic features that can induce atmospheric circulation possibly explaining such behaviour.

\subsection{Impact of thermal heat lows}

Large arid or semi-arid plateaus and steppes surrounded by mountains are key features of the Mediterranean region, where thermal heat lows form frequently, especially over the Sahara region and the Iberian and Arabian Peninsulas. Thermal heat lows could explain part of the peculiar absence of local humidity change as they form mostly during the warm seasons because of the intense surface heating over land and little surface evaporation. The basic physical process responsible for generating a thermal low is the vertical expansion of the lowermost layers of the atmosphere due to convective heating, which produces divergence above these layers. The divergence aloft results in a lowering of the surface pressure. In the Mediterranean, the Saharan heat low has been extensively studied as it controls part of the West African monsoon variability (e.g. Lavaysse et al., 2009) and is associated with extreme surface aridity which does not allow the formation of rain (Griffiths and Soliman 1972). Thermal lows over the Arabian Peninsula have been investigated by Smith (1986), and the Iberian heat low by Hoinka and De Castro (2003) and Portela and Castro (1996).

In order to characterize the regional thermal lows, we propose a criterion based on the heat-induced dilatation of the low levels used to identify the presence of the West African heat low (Lavaysse et al. 2009). To do so, we estimate the low-level atmospheric thickness (LLAT) between two pressure levels of the simulations. The upper-level boundary is chosen as $700 \mathrm{hPa}$. The lower boundary is selected as $925 \mathrm{hPa}$. The LLAT is related to the mean temperature of the layer by (Lavaysse et al. 2009):

$$
\Delta Z=\frac{R}{g} \int_{p_{1}}^{p_{2}} T d(\ln (p))
$$

where $\Delta \mathrm{Z}$ is the LLAT, $\mathrm{R}$ the gas constant for air, $\mathrm{g}$ gravitational acceleration, $\mathrm{T}$ temperature, $\mathrm{p}$ pressure, $\mathrm{p}_{1}=925 \mathrm{hPa}$ and $\mathrm{p}_{2}=700 \mathrm{hPa}$. In the present study, a small modification was brought in order to remove the impact of the latitudinal variation of temperature. Thus, T in Eq. (3) is replaced by $\widetilde{T}=T-\langle T\rangle_{x}$, where $\langle.\rangle_{x}$ indicates zonal averaging. As in Lavaysse et al. (2009), the heat low is defined as the area where the LLAT which characterizes the depth of the heat low exceeds a given (arbitrarily set) threshold, here set to the $90^{\text {th }}$ quantile of LLAT distribution computed over the whole Mediterranean domain. 
Figure 5 displays the heat low occurrence over the whole Mediterranean basin when exceeding 25\% (most frequent events) at the end of $21^{\text {st }}$ century. The pattern is very similar in the present climate, but with up to $10 \%$ lower occurrence with respect to the future climate. The West African and Arabic Peninsula heat lows are by far the most frequent and intense. For the Iberian Peninsula, the results found for the present climate are consistent with those of Hoinka and De Castro (2003) and Portela and Castro (1996) for both the annual variability of occurrence of thermal lows (with a maximum in summer around $40 \%$, and higher occurrence in spring ( 20\%) than autumn ( $10 \%)$ ), and the location of the lows centre, which is less variable in July than other months.

Typically, a low-level cyclonic circulation organises around the heat lows, in which shallow convection forms in the low, but precipitation does not occur (e.g. Hoinka and De Castro 2003; Engelstaedter et al. 2015). The surface heat low isolates the region from moisture advection, which is thus confined at the periphery of the heat low. There, strong pressure gradients cause low-level winds to blow from the coastal zones in an arc around the heat low core in a low-level cyclonic circulation. The cyclonic circulation above the Iberian Peninsula deviates the westerly flow and Atlantic water flux south of the peninsula. Similarly, the Saharan cyclonic circulation deviates the easterly flow of marine air from the Mediterranean Sea to the north of the African coast, further contributing to the water flux concentration south of the Iberian Peninsula. The cyclonic circulation is visible on the composite of Fig. 1, it is however much clearer when conditionaly sampled with respect to heat low occurrence (not shown). Therefore, the dynamical atmospheric conditions, which strengthen in a warmer climate, act as an obstacle to moisture transport in some regions of the Mediterranean and can prevent humidity increase with climate change.

In all simulations, the pattern remains unchanged in a future climate with respect to present, but the occurrence of the Iberian heat low increases (by about 5 to $7 \%$ in spring and summer in scenario RCP8.5). Indeed, the LLAT scales with temperature and therefore, it increases with climate change leading to an increased probability of occurrence of heat low situations. The higher occurrence of the Iberian heat low is associated with an enhanced horizontal gradient of temperature, as the temperatures warm over land. The warming is significantly stronger than that over the surrounding seas (Fig. 1). Such gradient is favourable to enhanced cyclonic circulation. The enhanced circulation diverts the zonal advection of humidity to the south of the Iberian Peninsula, reducing the advection of marine humid air towards the core of the heat low.

A way to quantify how much heat lows explain the extreme dryness in the heat low areas, is to quantify the humidity change conditionned to the occurrence of a heat low. Figure 3 shows $\Delta \mathrm{e} / \Delta \mathrm{e}_{\mathrm{s}}$ conditionned to the absence or the occurrence of heat low events at locations within the Saharan and Iberian heat lows (see $\times$ markers in Fig. 2a). The red squares which indicate the humidity change $\Delta \mathrm{e} / \Delta \mathrm{e}_{\mathrm{s}}$ in the absence of heat low events, are all the time within the uncertainty range around the values of humidity change $\Delta \mathrm{e}^{\mathrm{up}}{ }_{\text {sea }} / \Delta \mathrm{e}_{\mathrm{s}}$ assuming the upstream ocean as the only humidity source. Conversely, the diamonds represent the humidity change $\Delta \mathrm{e} / \Delta \mathrm{e}_{\mathrm{s}}$ in the presence of heat low events. The values are always lower and closer to the unconditional values $\Delta \mathrm{e} / \Delta \mathrm{e}_{\mathrm{s}}$ (black curve). The two conditional values (in the presence and in the absence of heat lows) are significantly different in autumn in Spain and in winter and autumn over the Sahara. The only case which conditional sampling approach hardly explains the very low values of humidity change is that in spring in Spain. The two conditional values lie in between $\Delta \mathrm{e}^{\text {up }}$ sea $/ \Delta \mathrm{e}_{\mathrm{s}}$ and $\Delta \mathrm{e} / \Delta \mathrm{e}_{\mathrm{s}}$ values but they are not significantly different. However, it seems reasonable to say that heat lows in the Mediterranean are a source of aridification amplification.

\section{Risk for human health}

Change of temperature and humidty has an impact on human health, which can be quantified using the humidex $(\mathrm{Hu})$ index. It can be interpreted as the thermal load due to air temperatures and water vapour pressures. Indeed, the human body normally cools itself by perspiration, or sweating. Heat is removed from the body by evaporation of that sweat. However, high relative humidity reduces the evaporation rate. This results in a lower rate of heat removal from the body which can have lethal consequences. The 
humidex is a dimensionless quantity, often recognized by the public as equivalent to the degree Celsius, given by

$$
H u=T+\frac{5}{9}\left[6.11 e^{5417.7530\left(\frac{1}{273.16}-\frac{1}{273.16 T_{d}}\right)}-10\right]
$$

where $\mathrm{T}$ is the air temperature and $\mathrm{T}_{\mathrm{d}}$ the dew point temperature, bothg expressed in ${ }^{\circ} \mathrm{C}$. The humidex range is associated with a scale of comfort that we classify in 4 categories :

- 20 to 29: little to no discomfort (category 1)

- 30 to 39: some discomfort (category 2)

- 40 to 45: great discomfort; avoid exertion (category 3)

- above 45: dangerous; heat stroke quite possible (category 4)

Figure 6 displays the humidex categories over the whole Mediterranean basin at the end of the $21^{\text {st }}$ century computed from the climate simulations. The pattern is very similar in the present climate but in some locations contoured in black solid line, the humidex category increases by +2 with respect to its category in the present climate. Unsuprisingly, the regions of higher risk are Northern Mediterranean and Southern Mediterranean. In spring and summer, the area of the regions of risk categories 1 to 4 increases by $+54 \%$ and $50 \%$, respectively. In winter and autumn, regions not exposed in the present climate should be exposed in a warmer climate. The trend in autumn is striking even though the severity of the risk appearing is limited to small disconfort. Figure 6 also shows that not only the regions of heat lows are those displaying the highest risk for human health, they also show the largest sensitivity to climate change. The case of the Iberian Peninsula stresses the role of the heat low in the change of humidex category which goes from category 1 or 2 to 3 or 4 so a situation which is dangerous for human health.

\section{Conclusion}

Feng and $\mathrm{Fu}$ (2013) showed that the area of global dryland is projected to expand by about $10 \%$ globally by 2100 . Nearly all regions, except India and northern tropical Africa, are projected to become dryer, with drying further intensifying during the 22nd century (Sherwood and Fu, 2014). In this paper, a closer look is given to the Mediterranean region, often referred to as a regional climate change "hot spot". Our study shows that although enhanced warming and drying over land is projected in the Mediterranean region, the spatial pattern displays high variability with regions of extreme warming and drying. Drying is in large part caused by enhanced warming over land. However, in Northern Europe, soil moisture is sufficient to counterbalance through evapotranspiration the warming effect by $15 \%$ (autumn and spring) to $50 \%$ (winter) due to humidity uptake from land. In the already arid regions of Southern Mediterranean, the situation is however contrasted. In the Eastern part, the Mediterranean Sea is the only humidity source and the drying effect is only due to warming over land. Over the Sahara region, and similarly over the Iberian Peninsula, the enhanced warming over land is still not enough to explain the extreme drying. Local water "recycling" through surface energy exchanges does not provide the full picture. The dynamics are also found to be key. More precisely, heat lows form over the Sahara and over the Iberian and Arabian Peninsulas as cyclonic circulation anomalies. The cyclonic circulation scales with the temperature gradient between land and sea. The gradient is expected to increase with climate change, reinforcing the cyclonic criculation over the Sahara and the Iberian Peninsula, both diverting the zonal advection of humidity to the south of the Iberian Peninsula over the Gibraltar Straight separating the European from the African continents. Therefore, the heat lows isolate the region where they form from humidity advection from the surrounding seas.

Warming and drying in the Mediterranean region can have detrimental consequences on human health due to the thermal load which accounts for air temperature and humidity. The risk exposure is expected to expand spatially with area increasing by about $50 \%$ and in severity with area of extreme danger increasing by $500 \%$. The largest change of risk category is found to be co-located with the heatlow regions where extreme warming and drying are projected. However, not accounted for in this study is the possible mitigating effect on warmng and drying of vegetation through the interactive phenology (Stéfanon et al., 2012b, 2014) or CO2 fertilization effect (Lemordant et al., 2016). The relative 
contribution of these various processes is still to be assessed but remains out of the scope of the present study.

\section{Acknowledgements}

This work is a contribution to the HyMeX program (HYdrological cycle in The Mediterranean EXperiment) through INSU-MISTRALS support and the MED-CORDEX program (COordinated Regional climate Downscaling EXperiment - Mediterranean region). It was supported by the IPSL group for regional climate and environmental studies. It is also a contribution to the cross-cutting activity on sub-daily precipitation of the GEWEX program of the World Climate Research Program (WCRP) (GEWEX Hydroclimate Panel).

\section{References}

Bador M, Terray L, Boé J, Somot S, Alias A, Gibelin AL, Dubuisson B 2017 Future summer megaheatwave and record-breakingtemperatures in a warmer France climate Environ. Res. Lett. 12 074025, doi:10.1088/1748-9326/aa751c

Bastin S, Drobinski P, Chiriaco M, Bock O, Roehrig R, Gallardo C, Conte D, Dominguez-Alonso M, Li L, Lionello P, Parracho A C 2019 Impact of humidity biases on light precipitation occurrence: Observations versus simulations Atmos. Chem. Phys. 19 1471-1490, doi:10.5194/acp-19-14712019

Bastin S, Champollion C, Bock O, Drobinski P, Masson F 2007 Diurnal cycle of water vapor as documented by a dense GPS network in a coastal area during ESCOMPTE-IOP2 J. Appl. Meteorol. Climatol. 46 167-82, doi:10.1175/JAM2450.1

Christidis N, Jones GS, Stott PA 2014 Dramatically increasing chance of extremely hot summers since the 2003 European heatwave Nat. Clim. Chang. 5 46-50, doi:10.1038/nclimate2468

Cuttelod A, García N, Abdul Malak D, Temple H, Katariya V 2008 The Mediterranean: a biodiversity hotspot under threat. In: J.-C. Vié, C. Hilton-Taylor and S.N. Stuart (eds). The 2008 Review of The IUCN Red List of Threatened Species. IUCN Gland, Switzerland.

Dai A 2006 Recent climatology, variability, and trends in global surface humidity J. Clim. 19 35893606, doi:10.1175/JCLI3816.1

Drobinski P, Bastin S, Arsouze T, Béranger K, Flaounas E, Stéfanon M 2018b North-Western Mediterranean sea-breeze circulation in a regional climate system model Clim. Dyn. 51 1077-1093, doi:10.1007/s00382-017-3595-z

Drobinski P, Da Silva N, Panthou G, Bastin S, Muller C, Ahrens B, Borga M, Conte D, Fosser G, Giorgi F, Güttler I, Kotroni V, Li L, Morin E, Onol B, Quintana-Segui P, Romera R, Torma CZ 2018a Scaling precipitation extremes with temperature in the Mediterranean: Past climate assessment and projection in anthropogenic scenarios Clim. Dyn. 51 1237-1257, doi:10.1007/s00382-016-3083-x

Drobinski P, Alonzo B, Bastin S, Da Silva N, Muller C J 2016 Scaling of precipitation extremes with temperature in the French Mediterranean region: what explains the hook shape? J. Geophys. Res. 121, doi:10.1002/2015JD023497

Drobinski P, Ducrocq V, Alpert P, Anagnostou E, Béranger K, Borga M, Braud I, Chanzy A, Davolio S, Delrieu G, Estournel C, Filali Boubrahmi N, Font J, Grubisic V, Gualdi S, Homar V, IvancanPicek B, Kottmeier C, Kotroni V, Lagouvardos K, Lionello P, Llasat M C, Ludwig W, Lutoff C, Mariotti A, Richard E, Romero R, Rotunno R, Roussot O, Ruin I, Somot S, Taupier-Letage I, Tintore J, Uijlenhoet R and Wernli H 2014 HyMeX, a 10-year multidisciplinary program on the Mediterranean water cycle Bull. Amer. Meteorol. Soc. 95 1063-82, doi:10.1175/BAMS-D-1200242.1

Feng S, Fu Q 2013 Expansion of global drylands under a warming climate Atmos. Chem. Phys. 13 10081-10094, doi:10.5194/acp-13-10081-2013

Fouillet A, Rey G, Laurent F, Pavillon G, Bellec S, Guihenneuc-Jouyaux C, Clavel J, Jougla E, Hémon D 2006 Excess mortality related to the august 2003 heat wave in France Int Arch Occup Environ Health 80 16-24, doi:10.1007/s00420-006-0089-4

Giorgi F 2006 Climate change hot-spots Geophys. Res. Lett. 33 L08707 doi:10.1029/2006GL025734

Hoinka K P and De Castro M 2003 The Iberian Peninsula thermal low Quart. J. Roy. Meteorol. Soc. 129 1491-1511, doi: 10.1256/qj.01.189 
IPCC. Summary for Policymakers. In Climate Change 2013: The Physical Science Basis. Contribution of Working Group I to the Fifth Assessment Report of the Intergovernmental Panel on Climate Change; Stocker, T., Qin, D., Plattner, G.K., Tignor, M., Allen, S., Boschung, J., Nauels, A., Xia, Y., Bex, V., Midgley, P., Eds.; Cambridge University Press: Cambridge, UK; New York, NY, USA, 2013; pp. 3-29.

Jacob D, Petersen J, Eggert B, Alias A, Christensen OB, BouwerLM, Braun A, Colette A, Déqué M, Georgievski G, Georgopoulou E, Gobiet A, Menut L, Nikulin G, Haensler A, Hempelmann N, Jones C, Keuler K, Kovats S, Kröner N, Kotlarski S, Kriegsmann A, Martin E, van Meijgaard E, Moseley C, Pfeifer S, Preuschmann S, Radermacher C, Radtke K, Rechid D, Rounsevell M, Samuelsson P, Somot S, Soussana JF, Teichmann C, Valentini R, Vautard R, Weber B, Yiou P 2013 EURO-CORDEX: New high-resolution climate change projections for European impact research Regional Environ. Change 14 563-578, doi:10.1007/s10113-013-0499-2

Köpen W 1936 : Das geographishe system der klimate. In Köpen and Geiger Eds, Handbuch der 784 Klimatologie 3. Gebrueder Borntraeger, Berlin, $46 \mathrm{pp}$.

Lavaysse C, Flamant C, Janicot S, Parker D J, Lafore J P, Sultan B, Pelon J 2009 Seasonal evolution of the West African heat low: a climatological perspective Clim. Dyn. 33 313-330, doi:10.1007/s00382-009-0553-4

Lemordant L, Gentine P, Stéfanon M, Drobinski P, Fatichi H 2016 Modification of land-atmosphere interactions by $\mathrm{CO} 2$ effects: Implications for summer dryness and heatwave amplitude Geophys. Res. Let. 43 10240-10248, doi: 10.1002/2016GL069896

Lionello P, Scarascia L 2018 The relation between climate change in the Mediterranean region and global warming Reg Environ Change 18: 1481-1493, doi:10.1007/s10113-018-1290-1

Mariotti A, Pan Y, Zeng N, Alessandri A 2015 Long-term climate change in the Mediterranean region in the midst of decadal variability Clim. Dyn. 44 1437-1456, doi:10.1007/s00382-015-2487-3

Mariotti A, Zeng N, Yoon J, Artale V, Navarra A, Alpert P, Li LZX 2008 Mediterranean water cycle changes: Transition to drier 21st century conditions in observations and CMIP3 simulations Env. Res. Lett. 3 044001, doi:10.1088/1748-9326/3/4/044001

Myers N, Mittermeier RA., Mittermeier CG., da Fonseca GAB, Kent J 2000 Biodiversity hotspots for conservation priorities. Nature. 403 853-858, doi:10.1038/35002501.

Muller C J, O'Gorman P A and Back L E 2011 Intensification of precipitation extremes with warming in a cloud resolving model J. Clim. 24 2784-2800, doi:10.1175/2011JCLI3876.1

O'Gorman P A and Muller C G 2010 How closely do changes in surface and column water vapour follow Clausius-Clapeyron scaling in climate change simulations? Env. Res. Lett. 5 025,207, doi: $10.1088 / 1748-9326 / 5 / 2 / 025207$

Portela A and Castro M 1996 Summer thermal lows in the Iberian Peninsula: A three-dimensional simulation Quart. J. Roy. Meteorol. Soc. 122 1-22, doi:10.1002/qj.49712252902

Priestley C H B, Taylor R J 1972 On the assessment of surface heat flux and evaporation using largescale parameters Mon. Wea. Rev. 100 81-92, doi:10.1175/15200493(1972)100<0081:OTAOSH>2.3.CO;2

Raymond F, Ullmann A, Tramblay Y, Drobinski P, Camberlin P 2018c Mediterranean extreme dry spells during the wet season: evolution in climate change scenarios Reg. Env. Change submitted (this issue)

Raymond F, Ullman A, Camberlin P, Oueslati B, Drobinski P 2018b Atmospheric conditions and weather regimes associated with extreme winter dry spells over the Mediterranean basin Clim. Dyn. 50 4437-4453, doi:10.1007/s00382-017-3884-6

Raymond F, Drobinski P, Ullman A, Camberlin P 2018a Extreme dry spells over the Mediterranean basin during the wet season: Assessment of HyMeX/Med-CORDEX regional climate simulations Int. J. Climatol. 38 3090-3105, doi:10.1002/joc.5487

Raymond F, Ullman A, Camberlin P, Drobinski P, Chateau Smith C 2016 Extreme dry spell detection and climatology over the Mediterranean basin during the wet season Geophys. Res. Lett. $437196-$ 7204, doi:10.1002/2016GL069758

Rowell D P, Jones R G 2006 Causes and uncertainty of future summer drying over Europe Clim. Dyn. 27 281-299, doi:10.1007/s00382-006-0125-9 
Russo S, Sillmann J, Fischer EM 2015 Top ten European heatwaves since 1950 and their occurrence in the coming decades Environ. Res. Lett. 10 124003, doi:10.1088/1748-9326/10/12/124003

Ruti P, Somot S, Giorgi F, Dubois C, Flaounas E, Obermann A, Dell'Aquila A, Pisacane G, Harzallah A, Lombardi E, Ahrens B, Akhtar N, Alias A, Arsouze T, Raznar R, Bastin S, Bartholy J, Béranger K, Beuvier J, Bouffies-Cloche S, Brauch J, Cabos W, Calmanti S, Calvet J C, Carillo A, Conte D, Coppola E, Djurdjevic V, Drobinski P, Elizalde A, Gaertner M, Galan P, Gallardo C, Gualdi S, Goncalves M, Jorba O, Jorda G, Lheveder B, Lebeaupin-Brossier C, Li L, Liguori G, Lionello P, Macias-Moy D, Onol B, Rajkovic B, Ramage K, Sevault F, Sannino G, Struglia M V, Sanna A, Torma C and Vervatis V 2016 MED-CORDEX initiative for Mediterranean climate studies Bull. Amer. Meteorol. Soc. 97 1187-1208, doi:10.1175/BAMS-D-14-00176.1

Scheff J, Frierson D M W 2015 Terrestrial aridity and its response to greenhouse warming across CMIP5 climate models J. Clim. 28 5583-5600, doi:10.1175/JCLI-D-14-00480.1

Sherwood S, Fu Q 2014 A drier future? Science 343 737-739, doi:10.1126/science.1247620

Simmons A J, Willett K, Jones P, Thorne P, Dee D 2010 Low-frequency variations in surface atmospheric humidity, temperature, and precipitation: Inferences from reanalyses and monthly gridded observational data sets J. Geophys. Res. 115 doi:10.1029/2009JD012442

Smith E A 1986 The structure of the Arabian heat low. Part I: Surface energy budget Mon. Weather Rev. 114 1067-1083, doi:10.1175/1520-0493(1986)114<1067:TSOTAH>2.0.CO;2

Solomon S, Qin D, Manning M, Alley R B, Berntsen T, Bindoff N L, Chen Z, Chidthaisong A, Gregory J M, Hegerl G C, Heimann M, Hewitson B, Hoskins B J, Joos F, Jouzel J, Kattsov V, Lohmann U, Matsuno T, Molina M, Nicholls N, Overpeck J, Raga G, Ramaswamy V, Ren J, Rusticucci M, Somerville R, Stocker T F, Whetton P, Wood R A and Wratt D 2007 Technical Summary. In: Climate Change 2007: The Physical Science Basis. Contribution of Working Group I to the Fourth Assessment Report of the Intergovernmental Panel on Climate Change [Solomon, S., D. Qin, M. Manning, Z. Chen, M. Marquis, K.B. Averyt, M. Tignor and H.L. Miller (eds.)]. Cambridge University Press, Cambridge, United Kingdom and New York, NY, USA.

Stéfanon M, Schindler S, Drobinski P, de Noblet-Ducoudré N, D'Andrea F 2014 Simulating the effect of anthropogenic vegetation land cover on heatwave temperatures over central France Clim. Res. 60 133-146, doi:10.3354/cr01230

Stéfanon M, Drobinski P, D’Andrea F, de Noblet-Ducoudré N 2012b Effects of interactive vegetation phenology on the 2003 summer heat waves J. Geophys. Res. 117 D24103, doi:10.1029/2012JD018187

Stéfanon M, D'Andrea F, Drobinski P 2012a Heatwave classification over Europe and the Mediterranean region Env. Res. Lett. 7014023 doi:10.1088/1748-9326/7/1/014023

Stegehuis AI, Vautard R, Ciais P, Teuling AJ, Miralles DG, Wild M 2015 An observation-constrained multi-physics WRF ensemble for simulating European mega heat waves Geoscientific Model Development 8 2285-2298, doi:10.5194/gmd-8-2285-2015, 2015.

Trenberth KE, Dai A, Rasmussen RM, Parsons DB 2003 The changing character of precipitation. Bull. Am. Meteorol. Soc. 84 1205-1217, doi:10.1175/BAMS-84-9-1205.

Xoplaki E, Gonzales-Rouco F J, Luterbacher J and Wanner H 2003 Mediterranean summer air temperature variability and its connection to the large-scale atmospheric circulation and SSTs Clim. Dyn. 20 723-39, doi:10.1007/s00382-003-0304-x 


\section{FIGURES}

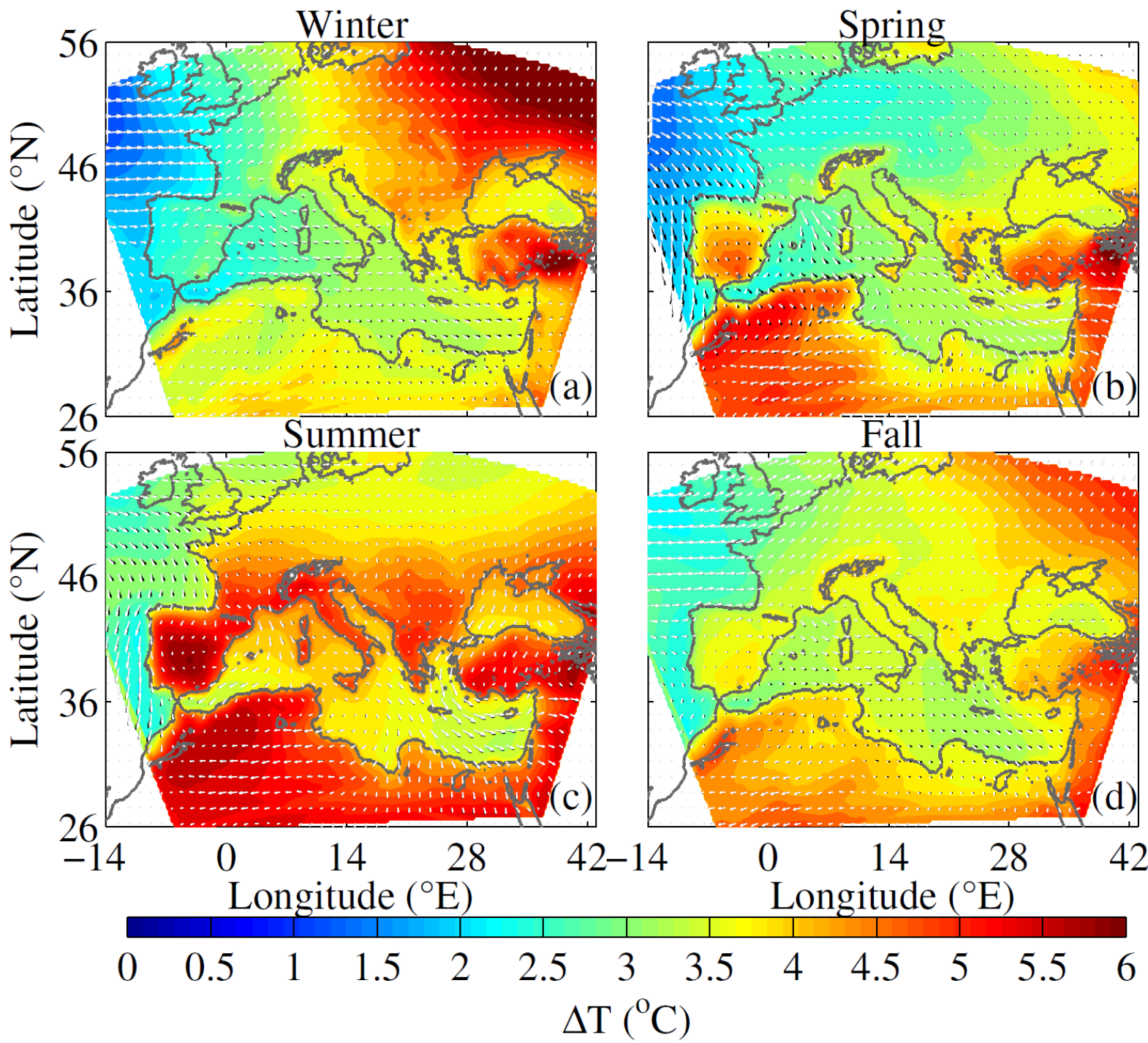

Figure 1: Temperature change between 2070-2100 and 1979-2005 for winter (a), spring (b), summer (c) and fall (d). The black and white arrows display the seasonal averaged wind fields in present and future climates, respectively. 


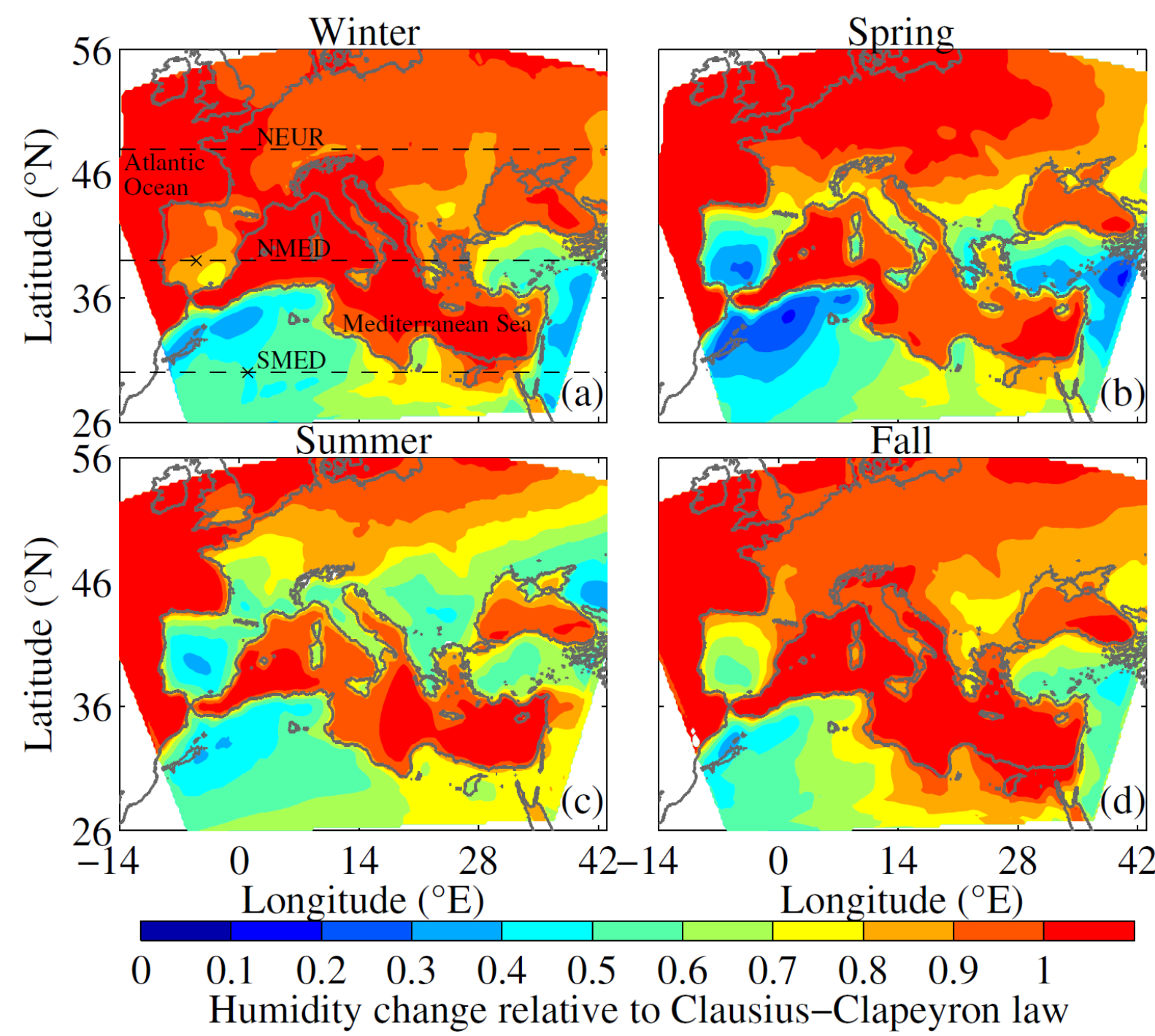

Figure 2 : Humidity change between 2070-2100 and 1979-2005, relative to Clausius-Clapeyron law for winter (a), spring (b), summer (c) and fall (d) over the domain common to the HyMeX/MED-CORDEX and EURO-CORDEX simulations. The dashed lines in panel a respresent cross-sections that will be used to differentiate processes occurring in Northern Europe (NEUR), Northern Mediterranean (NMED) (or equivalently Southern Europe) and Southern Mediterranean (SMED) (or equivalently North Africa). The $\times$ markers on the NMED and SMED cross-sections indicate locations where conditional humidity change is shown in Fig. 3. 

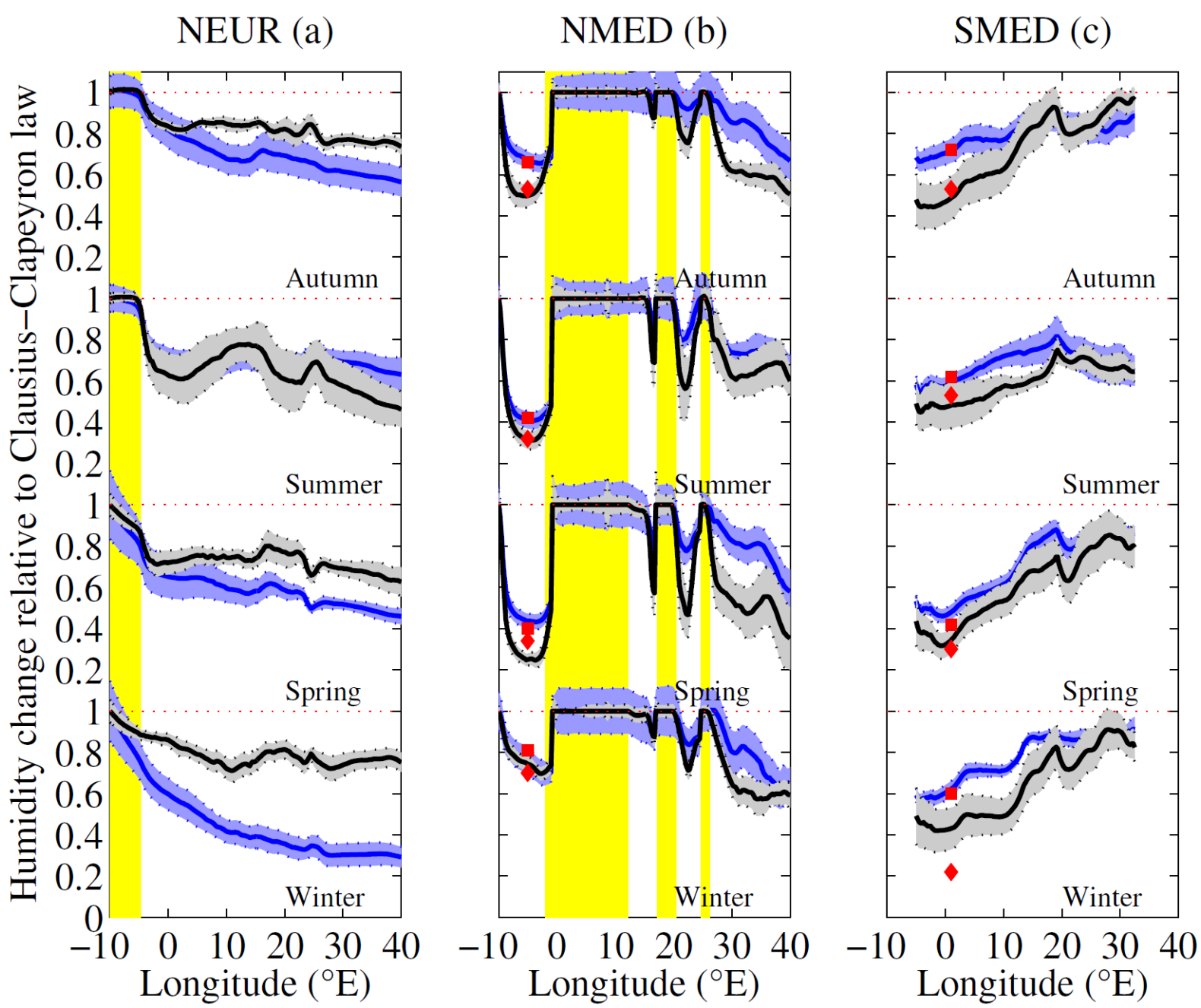

Figure 3: Humidity change $\Delta \mathrm{e} / \Delta \mathrm{e}_{\mathrm{s}}$ (black line) relative to CC law and humidity change $\Delta \mathrm{e}^{\text {up }}$ sea $/ \Delta \mathrm{e}_{\mathrm{s}}$ expected if the origin of the water over continent was from the upstream ocean only (blue line) along the North-European (NEUR) (a), the North-Mediterranean (NMED) (b) and the SouthernMediterranean (SMED) (c) cross sections (Fig. 1a). The thick black and blue lines corresponds to the ensemble average, while the shaded gray and blueish areas delimited by the black and blue dotted lines represent the 1- $\sigma$ interval. The yellow stripes display the regions over sea (Atlantic Ocean for NorthernEurope cross section, and the Mediterranean sub-basins including the Adriatic Sea for the North Mediterranean cross-section). The red squares and diamonds represent the humidity change conditioned to the absence of heat low events and to the occurrence of heat low events, respectively at the locations indicated by a " $x$ " along the NMED (Iberian Peninsula) and SMED (Sahara desert) cross-sections (Fig. 1a). 

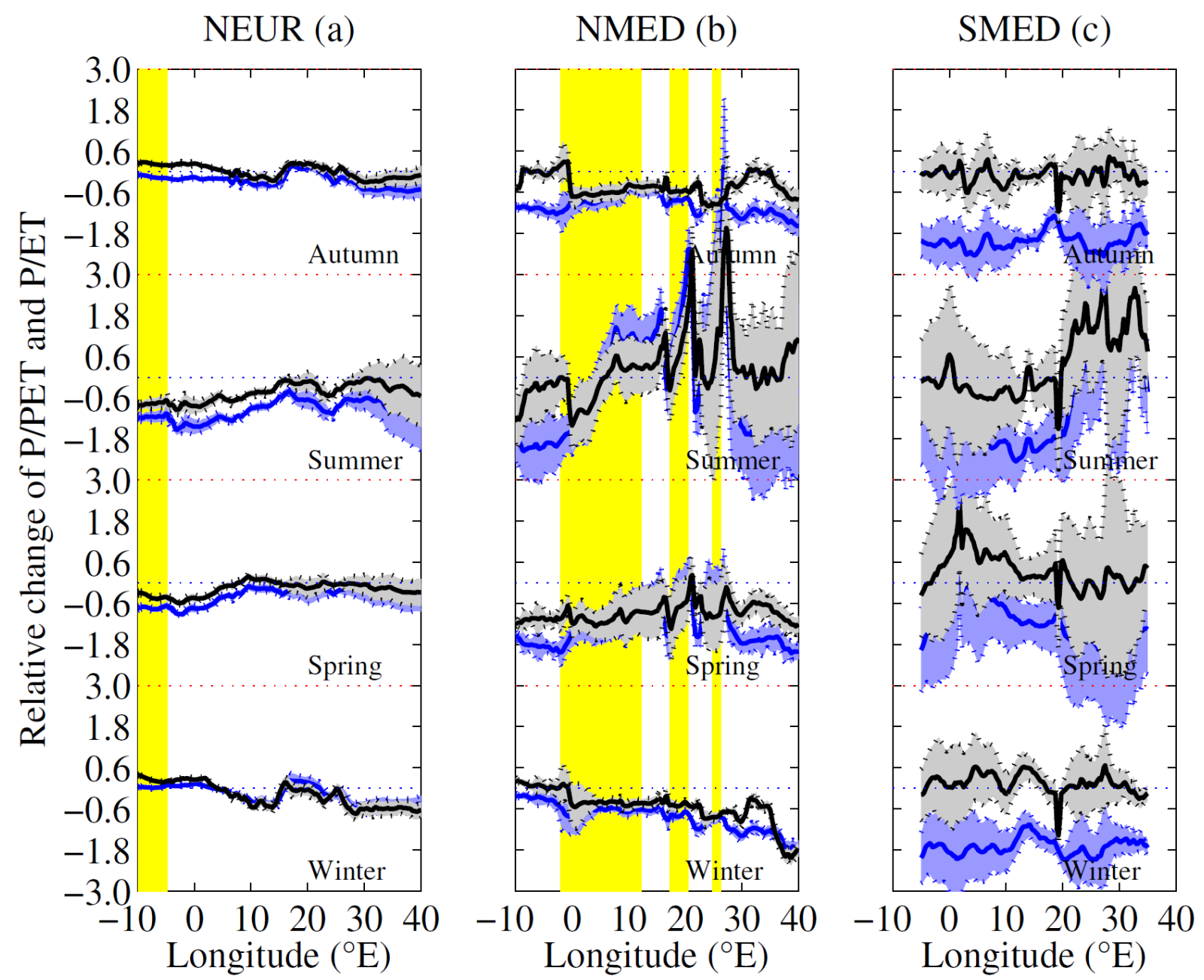

Figure 4: Same as Fig. 3 for the relative change of the ratio of precipitation to potential evapotranspiration P/PET (blue line) computed from Priestley-Taylor method and relative change of the ratio of precipitation to real evapotranspiration (P/ET) (black line). Note that for the SMED cross-section (c), the dotted lines represent the $\sigma / 10$ interval instead of $\sigma$ to keep the figure legible. 


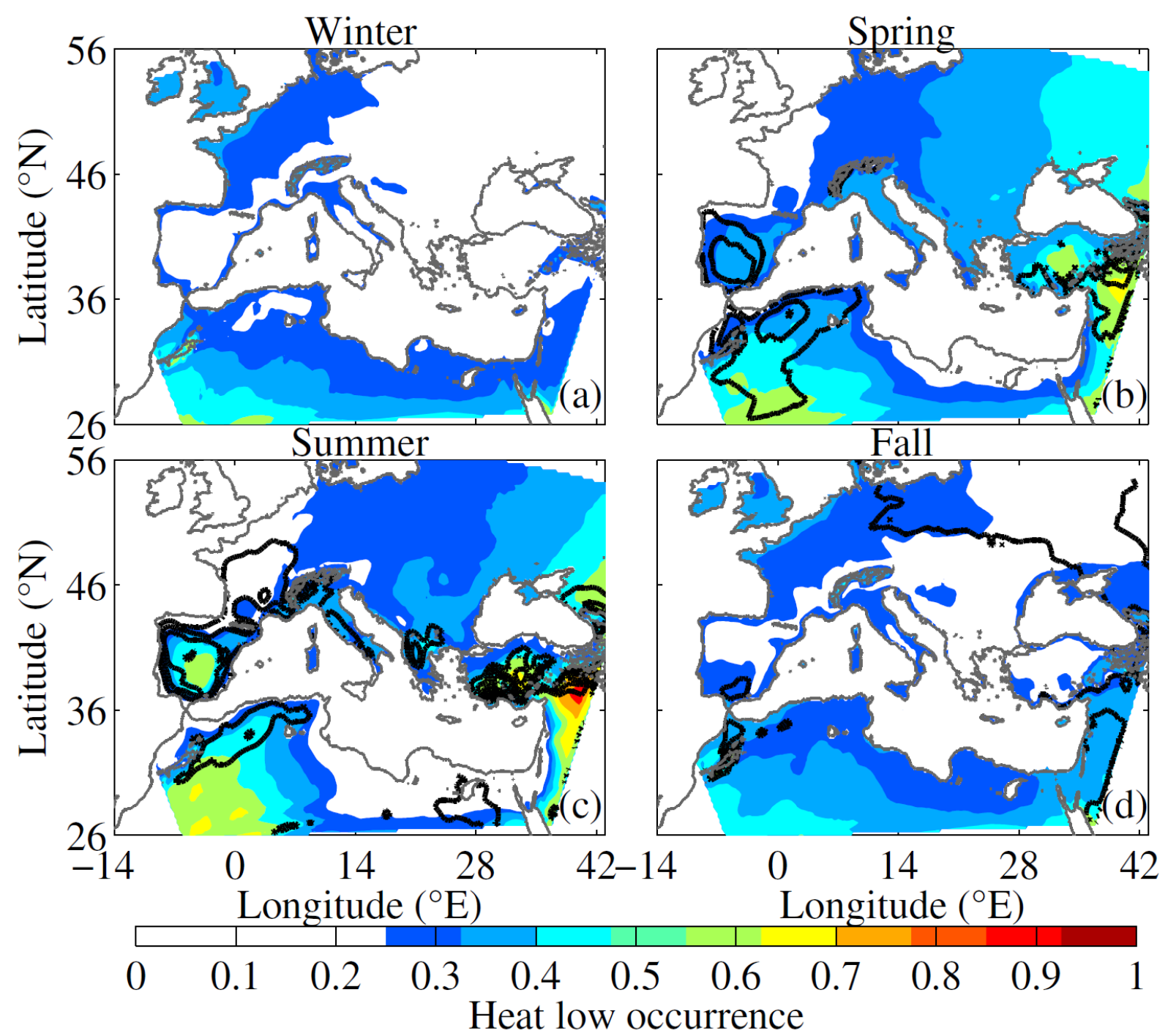

Figure 5 : Ensemble average of heat low occurrence in the future climate (2070-2100) for winter (a), spring (b), summer (c) and fall (d). The white zones correspond to the absence of data, to data over the sea or to heat low occurrence below 25\% (only the significant events are analyzed). The thick black lines display the change of heat low occurrence between present and future climates. The isocontours range between $+2.5 \%$ to $+20 \%$ with an increment of $2.5 \%$. 


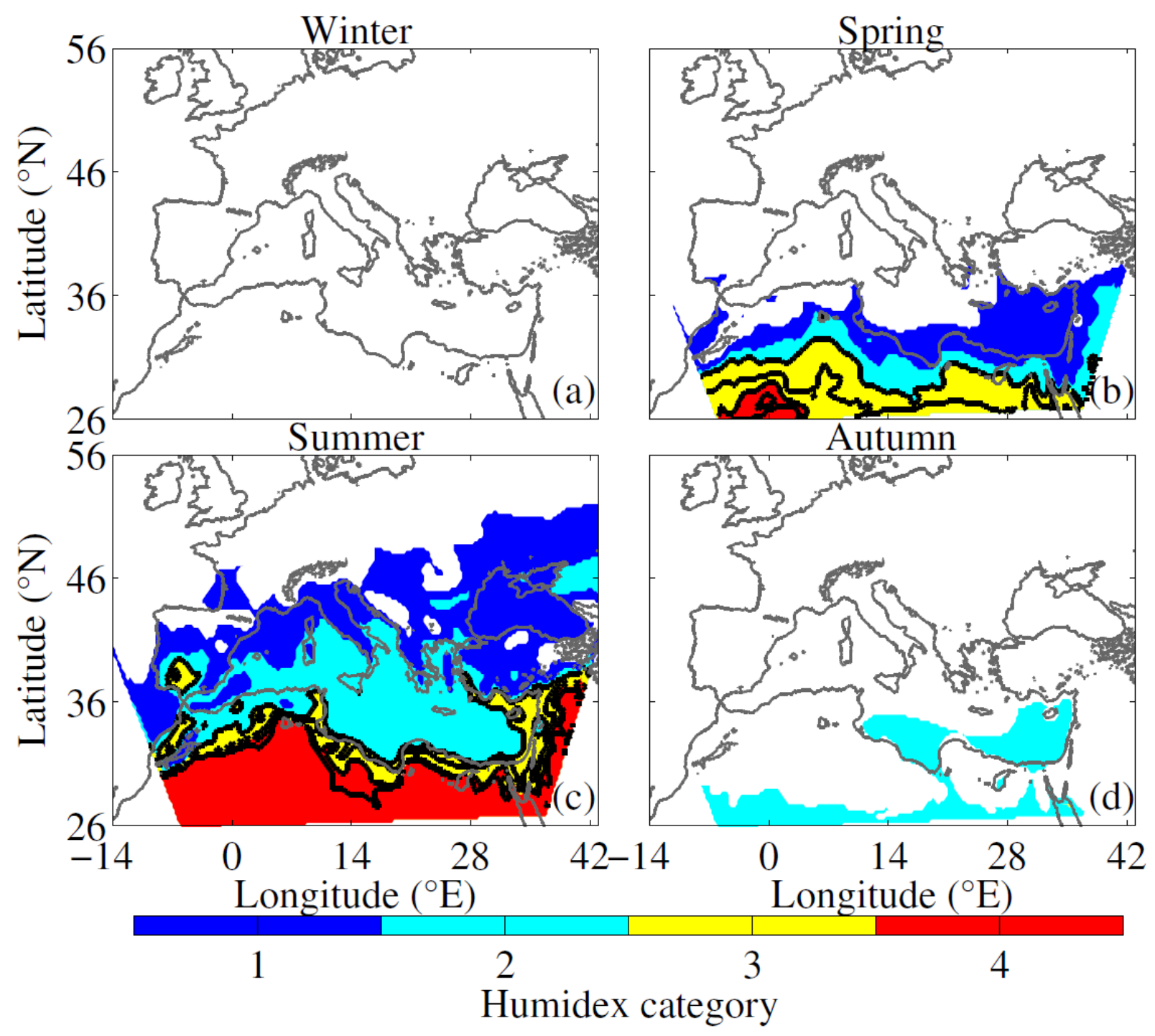

Figure 6 : Humidex category in the future climate (2070-2100) for winter (a), spring (b), summer (c) and fall (d). Category 1 corresponds to little to no discomfort, category 2 to some discomfort, category 3 to great discomfort and category 4 to dangerous. The white zones correspond to the absence of data, to data over the sea or to category 0 (no health risk) (only the significant events are analyzed). The thick black lines display the change of +2 category change between present and future climates. 